\title{
Studi Kelayakan Bisnis Bakso Lotus Jembar
}

\author{
Irna Novia Fitriani ${ }^{1}$, Agus Sudono ${ }^{1}$, Indriyani Handyastuti ${ }^{2}$ \\ ${ }^{1}$ Manajemen Industri Katering, Fakultas Pendidikan Ilmu Pengetahuan Sosial, Universitas \\ Pendidikan Indonesia, Jl. Dr. Setiabudhi No. 229, Bandung 40154, Indonesia \\ ${ }^{2}$ Meeting Insentif Conference Exhibition, Sekolah Tinggi Pariwisata Bandung, Jl. Dr. \\ Setiabudi No.186, Hegarmanah, Kec. Cidadap, Kota Bandung, Jawa Barat 40141
}

*Koresponding Penulis. E-mail: irnanovia@student.upi.edu (Irna Novia Fitriani)

\begin{abstract}
Abstrak
Penelitian yang dilakukan oleh penulis adalah Studi Kelayakan Bisnis Bakso Lotus Jembar yang bertujuan untuk menilai kondisi bisnis Bakso Lotus Jembar yang memiliki rencana untuk mengembangkan bisnis lebih lanjut apakah dapat layak untuk merealisasikan rencana tersebut atau tidak layak dan perlu ada peningkatan dalam semua aspek studi kelayakan bisnis. Metode analisis yang digunakan adalah metode yang merupakan campuran kualitatif dan kuantitatif. Populasi penelitian ini adalah konsumen Bakso Lotus Jembar, pemilik dan karyawan. Sampel yang digunakan untuk konsumen Bakso Lotus Jembar adalah sejumlah 95 orang konsumen, untuk mewawancarai pemilik menggunakan sampling jenuh dan stratified random sampling kepada karyawan. Hasil dari penelitian ini adalah aspek yang sudah layak adalah aspek pasar dan pemasaran, aspek keuangan, aspek teknis dan operasi, aspek manajemen dan organisasi, aspek manajemen sumber daya manusia, aspek ekonomi, aspek sosial dan budaya. Selanjutnya ada aspek yang tidak layak yaitu aspek hukum dan politik. Kesimpulan dari penelitian ini adalah secara keseluruhan Bakso Lotus Jembar sudah dapat dikatakan layak dengan beberapa rekomendasi yang harus diperbaiki. Hal utama yang harus diperbaiki adalah aspek hukum dan politik karena kedua aspek ini masih belum layak untuk dikembangkan. Bakso Lotus Jembar masih perlu menyelesaikan kewajiban terkait dengan pembentukan izin usaha. Lebih lanjut ke aspek - aspek lain yang bisa dikatakan dikembangkan
\end{abstract}

Kata Kunci: Bakso Lotus Jembar; Studi Kelayakan; Bisnis

\section{Pendahuluan}

Seiring dengan semakin pesatnya pertumbuhan wisata di Indonesia maka jumlah wisatawan ke Indonesia pun semakin meningkat. Destinasi wisata yang ditawarkan beragam dari mulai wisata alam, wisata edukasi, wisata religi bahkan sampai wisata kuliner. Kota Bandung merupakan salah satu daerah yang menyuguhkan berbagai kuliner yang menarik, kreatif dan inovatif. Maka banyak bermunculan pelaku usaha yang memanfaatkan hal ini untuk mendirikan suatu bisnis dibidang kuliner. Disaat persaingan bisnis yang semakin meningkat ada beberapa usaha kuliner yang masih bertahan dari dulu hingga sekarang. Bahkan penjualan semakin meningkat setiap tahunnya. Salah satunya adalah Bakso Lotus Jembar berdiri sejak tahun 1988 hingga sekarang. Usaha ini tetap mempertahankan kualitas produk serta cita rasa yang khas tak heran jika kuliner bakso ini masih digemari oleh konsumen. Tempat ini masih berkonsep restoran sederhana yang berkapasitas 55-60 orang. Untuk memenuhi permintaan yang semakin meningkat maka owner memiliki rencana untuk mengembangkan usaha tersebut lebih lanjut. Namun untuk mewujudkan hal itu perlu pertimbangan 
apakah usaha Bakso Lotus Jembar ini sudah layak atau tidak untuk dikembangkan lebih lanjut. Baik itu memperbesar usaha ataupun membuka cabang baru. Maka perlu dilakukannya suatu kajian yaitu tentang studi kelayakan bisnis. Dalam kajian tersebut terdapat aspek internal dan eksternal yang harus dikaji dalam penentuan layak atau tidak. Aspek internal yaitu diantaranya aspek hukum, aspek pasar dan pemasaran, aspek keuangan, aspek teknis dan operasi, aspek manajemen dan organisasi, dan aspek sumber daya manusia. Sedangkan untuk aspek eksternal diantaranya aspek ekonomi, aspek sosial dan budaya serta aspek politik. Berdasarkan latar belakang tersebut maka rumusan masalah Bakso Lotus Jembar sebagai berikut :

a. Bagaimana studi kelayakan bisnis Bakso Lotus Jembar dilihat dari aspek internal?

b. Bagaimana studi kelayakan Bakso Lotus Jembar dilihat dari aspek eksternal?

c. Bagaimana hasil keseluruhan dari studi kelayakan bisnis bakso lotus jembar?

Tujuan dari penelitian ini adalah untuk mengkaji serta mengetahui layak atau tidak usaha Bakso Lotus Jembar untuk dikembangkan lebih lanjut.

\subsection{Pengertian Pariwisata}

Menurut Undang-undang Republik Indonesia nomor 10 tahun 2009 pasal 1 tentang kepariwisataan menyatakan bahwa wisata adalah kegiatan perjalanan yang dilakukan oleh seseorang atau sekelompok orang dengan mengunjungi tempat tertentu untuk tujuan rekreasi, pengembangan pribadi, atau mempelajari keunikan daya tarik yang dikunjungi dalam jangka waktu sementara. Sedangkan Pariwisata adalah berbagai macam kegiatan wisata dan didukung berbagai fasilitas serta layanan yang disediakan oleh masyarakat, penguasaha, pemerintah, dan pemerintah daerah.

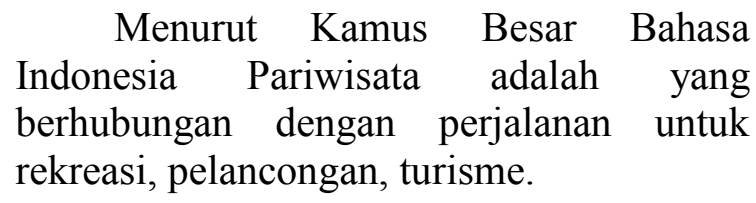

\subsection{Pengertian Restoran}

Menurut Marsum W.A (2005, hlm. 7) Restoran adalah suatu tempat atau bangunanyang diorganisasikan secara komersial , yang menyelenggarakan pelayanan dengan baik kepada semua tamunya baik berupa makanan ataupun minuman. Restoran ada yang berada dalam suatu hotel, kantor maupun pabrik, dan banyak juga yang berdiri sendiri di luar bangunan itu.

1.3. Pengertian Studi Kelayakan Bisnis

Menurut Kasmir dan Jakfar (2012, hlm. 7) Studi Kelayakan Bisnis (SKB) adalah suatu kegiatan yang mempelajari secara mendalam tentang suatu usaha atau bisnis yang akan dijalankan, dalam rangka menentukan layak atau tidak usaha tersebut dijalankan.

Adapun definisi lain tentang studi kelayakan bisnis yaitu menurut Suwinto Johan (2011, hlm. 8) yaitu studi kelayakan bisnis adalah sebuah studi untuk mengkaji secara kemperhensif dan mendalam terhadap kelayakan sebuah usaha.

\subsection{Tujuan Studi Kelayakan Bisnis}

Menurut Kasmir dan Jakfar (2012, hlm. 12) Paling tidak ada lima tujuan mengapa sebelum suatu usaha atau proyek dijalankan perlu dilakukan studi kelayakan, yaitu :
a. Menghindari resiko kerugian
b. Memudahkan perencanaan
c. Memudahkan pelaksanaan pekerjaan
d. Memudahkan pengawasan
e. Memudahkan pengendalian

\subsection{Aspek - Aspek Penilaian Bisnis}

Menurut Kasmir dan Jakfar (2012, hlm.8) ada beberapa aspek yang perlu dilakukan studi untuk menentukan 
kelayakan suatu usaha. Masing-masing aspek tidak berdiri sendiri, akan tetapi saling berkaitan. Artinya jika salah satu aspek tidak terpenuhi, maka perlu dilakukan perbaikan atau tambahan yang diperlukan.

\subsubsection{Aspek hukum}

Menurut Kasmir dan Jakfar (2012, hlm. 24) mengatakan bahwa tujuan dari aspek hukum adalah untuk meneliti keabsahan, kesempurnaan dan keaslian dari dokumen -dokumen yang dimiliki.Penelitian keabsahan dokumen dapat dilakukan sesuai dengan lembaga yang mengeluarkan dan yang mengesahkan dokumen yang bersangkutan.

\subsubsection{Aspek Pasar dan Pemasaran}

\section{a. Pengertian Pasar}

Menurut Suwinto Johan (2011, hlm.

40) menjelaskan bahwa Pasar merupakan tempat berkumpul para penjual yang menawarkan barang atau jasa kepada para pembeli yang mempunyai keinginan dan kemampuan untuk membeli barang dan jasa tersebut hingga terjadinya kesepakatan transaksi atau transfer atas kepemilikan barang atau kenikmatan jasa.

Dalam aspek pasar setidaknya terdapat tiga hal yang diperhatikan yaitu diantaranya, segementasi pasar, pasar sasaran, dan posisi pasar

\section{b. Pengertian Pemasaran}

Menurut Kasmir dan Jakfar (2012, hlm. 47) menjelaskan bahwa Pemasaran dapat pula diartikan sebagai upaya untuk menciptakan dan menjual produk kepada berbagai pihak dengan maksud tertentu.Pemasaran berusaha menciptakan dan mempertukarkan produk baik barang maupun jasa kepada konsumen dipasar.

\section{c. Bauran Pemasaran}

Menurut Kotler dan keller (2012, hlm.56) bauran pemasaran atau marketing mix adalah penyaluran dan komunikasi nilai-nilai pelanggan (costumer value) kepada pasar. Ada empat komponen dari bauran pemasaran atau marketing mix untuk masuk ke pasar, yaitu perusahaan memiliki produk yang bagus dan sesuai dengan target pasar (product). Kemudian produk tersebut harus memiliki harga yang sesuai target pasar (price). Keberhasilan memasuki pasar juga ditentukan oleh lokasi (place) dan melalui promosi (promotion) yang tepat agar produk dapat diterima sesuai dengan target pasar.

\subsubsection{Aspek Keuangan}

Menurut Kasmir dan Jakfar (2012, hlm. 89) menjelaskan bahwa aspek keuangan merupakan aspek yang digunakan untuk menilai keuangan perusahaan secara keseluruhan.

Menurut Kasmir dan Jakfar (2012, hlm.100) Adapun kriteria yang biasa digunakan untuk menentukan kelayakan suatu usaha atau investasi adalah :

\section{a. Payback period (PP)}

Metode ini merupakan teknik penilaian terhadap jangka waktu (periode) pengembalian investasi suatu proyek atau usaha.Perhitungnan ini dapat dilihat dari perhitungan kas bersih yang diperoleh setiap tahun. Nilai kas bersih merupakan penjumlahan laba setelah pajak ditambah dengan penyusutan (dengan catatan jika investasi $100 \%$ menggunakan modal sendiri)

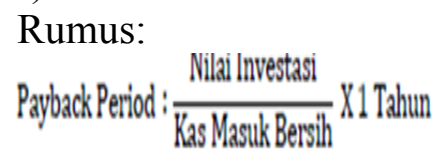

Kriteria penilaian :

Jika payback period lebih pendek waktunya dari maksimum payback periodnya maka usulan investasi dapat diterima.

b. Average Rate of Return (ARR)

Metode ini cara untuk mengukur ratarata pengembalian dengan cara membandingkan antara rata-rata laba sebelum pajak (EAT) dengan rata-rata investasi.

$$
\mathrm{ARR}=\frac{\text { laba setelah pajak }}{\text { Investasi awal }} \times 100 \%
$$

Jadi, dari kasus diatas bisa dicari ARR-nya sebagai berikut, pertama dengan mencari rata-rata EAT-nya lebih dahulu baru 
kemudian dicari ARR. Hasil nilai dari ARR dapat dikatakan layak apabila ARR > tingkat suku bunga.

c. Net Present Value (NPV)

Metode ini merupakan

perbandingan antara PV kas bersih (PV of Procced) dan PV investasi (capital outlays) selama umur investasi.Selisish antara kedua PV tersebutlah yang kita kenal dengan net present value.

Rumus :

$$
N P V=\sum_{t=1}^{n} \frac{C F t}{(1+K)^{t}}-I_{0}
$$

Keterangan :

$\mathrm{CFt}=$ aliran kas pertaruhan pada periode $\mathrm{t}$

$\mathrm{I} 0=$ investasi awal pada tahun 0

$\mathrm{K}=$ suku bunga (discount rate)

Kriteria penilaian :

- Jika NPV >0, maka usulan proyek diterima

- Jika NPV <0, maka usulan proyek ditolak

- Jika NPV $=0$, maka perusahaan tetap walau usulan proyek diterima atau ditolak

\section{d. Internal Rate of Return}

Metode ini merupakan alat untuk mengukur tingkat pengembalian hasil intern. Serta menghitung tingkat bunga yang dapat menyamakan antara present value dari laba bersih dengan kas keluar dari investasi yang dikeluarkan. Rumus:

Keterangan :

$$
R=P 1-C 1 \frac{P 2-P 1}{C 2-C 1}
$$

$\mathrm{C} 1=\mathrm{NPV} 1$

$\mathrm{C} 2=\mathrm{NPV} 2$

$\mathrm{V}=$ tingkat bunga kedua

$\mathrm{R}=$ IRR yang dicari

$\mathrm{P} 1=$ tingkat bunga pertama

e. Profitability Index (PI)

Metode ini merupakan rasio aktivitas dari jumlah nilai sekarang penerimaan bersih dengan nilai sekarang pengeluaran investasi selama umur investasi.
Rumus :

$$
\text { PI } \frac{\text { PV Kas bersih }}{\text { PV Kas investasi }}
$$

Kriteria penilaian :

- Jika PI >1, maka usulan proyek dikatakan menguntungkan.

- Jika PI $<1$, maka usulan proyek tidak dikatakan tidak menguntungkan.

Kriteria ini erat hubungannya dengan kriteria NPV, dimana jika NPV suatu proyek dikatakan layak (NPV $>0)$ maka menurut kriteria PI juga layak (PI >1) karena keduanya menggunakan variabel yang sama.

\subsubsection{Aspek Teknis dan Produksi}

Aspek teknis atau operasi juga dikenal sebagai aspek produksi. Menurut Kasmir dan Jakfar (2012, hlm.150) hal-hal yang diperhatikan dalam aspek ini adalah masalah penentuan lokasi, luas produksi, tata letak (layout), penyusunan peralatan pabrik, dan proses produksinya termasuk pemilihan teknologinya. Kelengkapan kajian aspek operasi sangat tergantung dari jenis usaha yang akan dijalankan, karena setiap jenis usaha memiliki proritas tersendiri.

\subsubsection{Aspek Manajemen}

Menurut Kasmir dan Jakfar (2012, hlm. 168) mengatakan bahwa aspek ini merupakan aspek yang cukup penting dianalisis untuk kelayakan Studi Kelayakan Bisnis. Karena walaupun suatu usaha telah dinyatakan layak untuk dilaksanakan tanpa didukung dengan manajemen dan organisasi yang baik, bukan tidak mungkin akan mengalami kegagalan.

Didalam manajemen dal yang perlu dianalisis adalah tentang perencanaan, pengorganisasian,pelaksanaan,pengawa san dengan baik untuk mencapai tujuan perusahaan atau prganisasi tersebut.

\subsubsection{Aspek Manajemen Sumber Daya Manusia}

Menurut Kasmir dan Jakfar (2012, hlm. 172) menjelaskan bahwa manajemen sumber daya manusia merupakan suatu 
konsep yang bertalian denga kebijaksanaan prosedur dan praktik bagaimana mengelola atau mengatur orang dalam perusahaan untuk mencapai tujuan yang telah ditetapkan.

Manajemen sumber daya dapat dijabarkan dalam fungsi manajerial yang meliputi perencanaan,

pengorganisasian, pengarahan dan pengawasan, dan fungsi operatif yang meliputi pengadaan, kompensasi, pengembangan, integrasi, pemeliharaan dan pemutusand hubungan kerja.

\subsubsection{Aspek Ekonomi}

Menurut Kasmir dan Jakfar (2012, hlm.201) dalam aspek ekonomi dan sosial dampak positif yang diberikan dengan adanya investasi atau suatu usaha lebih ditentukan kepada masyarakat khususnya dan pemerintah umumnya. Dalam aspek ini yang perlu diperhatikan adalah apakah jika usaha atau proyek dijalankan akan memberikan manfaat secara ekonomi dan sosial kepada berbagai pihak atau sebaliknya.

\subsubsection{Aspek Sosial dan Budaya}

Menurut Husein Umar (2003, hlm.252) tujuan utama perusahaan adalah mencari keuntungan yang sebesarnyabesarnya.Namun demikian, perusahaan tidak dapat hidup sendirian.Perusahaan hidup dengan komponen lain dalam satu tatanan kehidupan yang pluralistis dan kompleks, walau hendaknya selalu berada dalam keseimbangan.

\subsubsection{Aspek Politik}

Menurut Husein Umar (2003, hlm.256) adanya isu atau rumor maupun spekulasi yang timbul akibat kondisi politik yang diciptakan pemerintah akan mempengaruhi permintaan dan penawaran suatu produk, baik itu produk barang maupun jasa. Dalam skb hendaknya dikaji untuk memperkirakan bahwa situasi politik saat bisnis dibangun dan diimplementasikan tidak akan sangat mengganggu sehingga kajiannya menjadi layak. Situasi politik dapat diketahui melalui berita-berita di media masa.

\section{Metode Penelitian}

Metode penelitian ini menggunakan mix method yaitu metode kualitatif dan metode kuantitatif. Kedua metode ini dipilih karena dalam penelitian ini akan menghasilkan data yang berupa data primer. Data primer yaitu data yang diperoleh secara langsung dilapangan melalui survei, wawancara dan kuesioner. (Sugiyono, 2012 hlm. 193).

Subyek peneltian ini bertempat di Jl. Awi Bitung No.3, Cicadas, Cibeunying Kidul, Kota Bandung, Jawa Barat. 40121. Nomor telpon 0812-2241-4089.

Populasi dari penelitian ini adalah terdiri dari responden yang merupakan konsumen dari Bakso Lotus Jembar, owner yang merupakan pemillik restoran, serta karyawan.

Teknik sampling yang dilakukan penulis adalah sampling aksidental untuk kuesioner kepada konsumen Bakso Lotus Jembar dengan sampel 95 orang konsumen, sampling jenuh untuk teknik wawancara bersama owner serta sampling stratified random sampling untuk wawancara bersama karyawan.

Penulis dalam penelitian ini mengumpulkan data dengan teknik interview (wawancara), kuesioner (angket), observasi, dokumentasi dan studi literatur.

\section{Hasil dan Pembahasan}

Bakso Lotus Jembar merupakan sebuah bisnis dibidang kuliner khususnya bakso yang menyediakan berbagi macam varian bakso dan mie. Bisnis ini merupakan bisnis milik perseorangan atu milik pribadi. Berbagai macam varian menu ditawarkan disini bukan hanya bakso tetapi Bakso Lotus Jembar juga menawarkan berbagai varian menu minuman mulai dari es campur hingga berbagai macam jus. Berdasarkan hasil wawancara penulis bersama owner bahwa kelemahan yang dihadapi sekarang adalah tentang pengembangan bisnis. Karena jika 
dilihat dari pendapatan Bakso Lotus Jembar cukup mengalami kenaikan yang cukup signifikan.

Untuk itu penulis akan membantu owner untuk mengkaji bisnis tersebut dengan melakukan penelitian studi kelayakan bisnis Bakso Lotus Jembar dari berbagai aspek yaitu aspek internal dan eksternal.

\subsection{Aspek Hukum}

Berdasarkan hasil wawancara tersebut mengenai aspek hukum maka dapat dikatakan bahwa Bakso Lotus Jembar ini belum layak untuk dikembangkan karena dalam aspek hukum untuk perizinanperizinan usaha sangat diperlukan bukan hanya sekedar kewajiban saja untuk mengikuti peraturan pemerintah. Namun hal itu dapat menjaga usaha kita supaya tidak menimbulkan masalah dikemudian hari. Inilah yang menjadi kelemahan dari usaha Bakso Lotus Jembar.

\subsection{Aspek Pasar dan Pemasaran}

Berdasarkan hasil observasi dan wawancara bersama owner bahwa untuk aspek pasar segmentasi yang ditargetkan semua masayaakat kota Bandung khususnya daerah jembar, cicadas kota bandung, menyasar semua kalangan baik itu dewasa maupun remaja dan laki-laki mapun perempuan. Sedangkan untuk pasar sasaran serta posisi pasar menargetkan bahwa pasar sasaran yaitu semua masyarakat yang menyukai kuliner bakso dan untuk posisi pasar Bakso Lotus Jembar ingin menempatkan usaha ini sebagai pelopor bakso yang lezat di kota bandung.

Tabel 1. Kesimpulan dari Aspek Pemasaran (4P)

\begin{tabular}{clc}
\hline No & Bauran Pemasaran & Kategori \\
\hline 1 & Product & Baik \\
2 & Price & Baik \\
3 & Place & Cukup \\
4 & Promotion & Cukup \\
\hline
\end{tabular}

Berdasarkan Tabel 1 terlihat bahwa secara keseluruhan untuk aspek pemasaran berada dalam kategori baik. Sedangkan untuk kekurangan dari tempat adalah ketersediaan lahan parkir yang terbatas dan untuk promosi Bakso Lotus Jembar belum memaksimalkan promosi dari media sosial. Begitu dengan hasil wawancara bersama owner bahwa untuk kualitas prodauk sangat diperhatikan mulai dari cita rasa, kebersihan serta kesegaran produk.

Maka dari itu untuk aspek pasar dan pemasaran Bakso Lotus Jembar sudah dapat dikatakan layak untuk dilanjutkan.

\subsection{Aspek Keuangan}

Untuk mengetahui layak atau tidaknya dalam suatu usaha dilihat dari aspek keuangannya adalah dengan cara perhitungan metode penilaian investasi.

Kas masuk diperoleh dari pendapatan Bakso Lotus Jembar selama periode 4 tahun terakhir yaitu tahun 2014-2017 dengan jumlah Rp.4.407.736.000 dengan jumlah rata- rata Rp.1.101.934.000 Sedangkan untuk biaya operasional dan biaya tetap diperoleh dari biaya yang dikeluarkan oleh owner setiap tahunnya. Jumlah biaya operasional selama 4 tahun terakhir Rp.1.381.134.500 dengan jumlah rata-rata Rp.345.283.625. untuk biaya tetap yang dikeluarkan berjumlah Rp.169.900.000 dengan jumlah rata- rata Rp.42.475.000. Maka jumlah laba bersih yang didapat selama 4 tahun terakhir adalah Rp.2.856.701.500 dengan jumlah ratarata $\mathrm{Rp} .714 .175 .375$.

Untuk jumlah investasi awal Bakso Lotus Jembar adalah sebesar Rp. 1.232.766.000.

\subsubsection{Payback Priode (PP)}

Menurut Kasmir dan Jakfar (2012, hlm.100) metode ini merupakan teknik penilaian terhadap jangka waktu (periode) pengembalian investasi suatu proyek atau usaha.

$$
\text { Payback Period : } \frac{\text { Nilai Investasi }}{\text { Kas Masulk Bersih }} \text { X1 Tahum }
$$


Keterangan :

- Nilai investasi: didapat dari jumlah investasi awal perusahaan

- Kas masuk bersih :didapat dari rata-rata pendapatan selama 4 tahun terakhir

Berikut perhitungan payback periode bakso lotus jembar berdasarkan rumus diatas :

$$
\begin{aligned}
\mathrm{PP}= & \frac{1.232 .766 .000}{1.101 .934 .000} \times 1 \text { Tahun } \\
= & 1,118 \\
& 0,118 \times 365=43,07 \text { hari } \\
& 43,07 \div 30 \text { hari }=1,435 \text { bulan } \\
& 0.435 \times 30 \text { hari }=13,05 \text { hari }
\end{aligned}
$$$$
\text { Berdasarkan hasil perhitungan }
$$

diatas maka dapat disimpulkan bahwa pengembalian investasi Bakso Lotus Jembar adalah 1 tahun 1 bulan 12 hari. Karena itu Bakso Lotus Jembar dapat dikatakan layak karena pengembalian investasi lebih singkat daibandingkan dengan waktu pengembalian maksimum yaitu 3 tahun.

\subsubsection{Average Rate of Return (ARR)}

Perhitungan ARR dilakukan untuk mengukur tingkat keuntungan dari suatu investasi. Untuk menghitung ARR rumus yang digunakan adalah sebagai berikut :

$\mathrm{ARR}=$ laba setelah pajak $\times 100 \%$ Investasi awal

$\mathrm{ARR}=1.101 .934 .000 \times 100 \%$

1.232 .766 .000

$$
\mathrm{ARR}=89,39 \%
$$

Keterangan :

- Laba setelah pajak: didapat dari nilai rata-rata pendapatan 4 tahun terakhir

- Investasi awal : didapat dari biaya investasi awal

Berdasarkan hasil perhitungan diatas maka Bakso Lotus Jembar dapat dikatakan layak karena hasil tersebut sudah melebihi suku bunga yaitu 4,75\%. Maka ARR Bakso
Lotus Jembar adalah 89,39\% > 4,75 \%.

\subsubsection{Net Present Value (NPV)}

Menurut Kasmir dan Jakfar (2012, hlm.100) metode ini merupakan perbandingan antara PV kas bersih (PV of Procced) dan PV investasi (capital outlays) selama umur investasi. Selisish antara kedua PV tersebutlah yang kita kenal dengan net present value. Berikut perhitungan NPV Bakso Lotus Jembar :

$$
\begin{aligned}
& N P V=\sum_{t=1}^{n} \frac{C F t}{(1+K)^{t}}-I_{0} \\
& N P V=\underline{484.246 .500}+\underline{592617000}+\underline{726711500}+\underline{1053126500}-1.232 .766 .000 \\
& (1+0,475)^{1}(1+0,475)^{2}(1+0,475)^{3}(1+0,475)^{4} \\
& \mathrm{NPV}=\underline{484.246 .500}+\underline{592617000}+\underline{726711500}+\underline{1053126500}-1.232 .766 .000 \\
& (1,0475) \quad(1,0972) \quad(1,1493) \quad(1,2038) \\
& \mathrm{NPV}=2.509 .548 .432-1.232 .766 .000
\end{aligned}
$$

Berdasarkan hasil perhitungan NPV diatas Bakso Lotus Jembar dapat dikatakan layak karena nilai NPV tersebut lebih dari nol dimana nilai nol tersebut adalah biaya investasi awal maka NPV Rp.1.276.782.432 $>$ Rp.1.232.766.000 dapat dikatakan layak untuk dilanjutkan.

\subsubsection{Internal Rate of Return (IRR)}

Perhitungan ini dilakukan untuk mengetahui serta menghitung tingkat bunga yang dapat menyamakan antara present value dari laba bersih dengan kas keluar dari investasi yang dikeluarkan. Untuk menghitung IRR maka rumus yang digunakan adalah sebagai berikut :

Dimana :
$\mathrm{C} 1=\mathrm{NPV} 1$
$\mathrm{C} 2=$ NPV 2
$\mathrm{R}=$ IRR yang dicari
$\mathrm{P} 1=$ tingkat bunga pertama
P2 tingkat bunga kedua

Tabel 2. Perhitungan IRR

\begin{tabular}{cccccc}
\hline \multirow{2}{*}{ Tahun } & \multirow{2}{*}{ Proceeds } & \multicolumn{2}{c}{ Tingkat Bunga 37\% } & \multicolumn{2}{c}{ Tingkat Bunga 40\% } \\
\cline { 3 - 5 } & & DF & PV & DF & PV \\
\hline 1 & 484.246 .500 & 0,6947 & 336.406 .044 & 0,7143 & 345.897 .275 \\
2 & 592.617 .000 & 0,5387 & 319.242 .778 & 0,5102 & 3.023 .531 .932$. \\
3 & 726.711 .500 & 0,3964 & 288.068 .439 & 0,3644 & 1.264 .813 .671 \\
4 & 1.053 .126 .500 & 0,2911 & 306.565 .124 & 0,2603 & 274.128 .828 \\
\hline
\end{tabular}




\begin{tabular}{cccccc}
\hline \multirow{2}{*}{ Tahun } & \multirow{2}{*}{ Proceeds } & \multicolumn{2}{c}{ Tingkat Bunga 37\% } & \multicolumn{2}{c}{ Tingkat Bunga 40\% } \\
\cline { 2 - 5 } & & DF & PV & DF & PV \\
\hline & PV Proceeds & & 1.250 .282 .384 & & 1.187 .192 .967 \\
Investasi & & 1.232 .766 .000 & & 1.232 .766 .000 \\
NPV & & 17.516 .384 & & 45.573 .033 \\
\hline
\end{tabular}

Sumber: data diolah penulis, 2018

$\mathrm{R}=\mathrm{P} 1-\mathrm{C} 1$

$\mathrm{R}=37-17516384 \quad 40-37$

$(-45573033)-17516384$

$\mathrm{R}=37-(-0.832931335) \mathrm{R}=38 \%$

Berdasarkan hasil perhitungan diatas dapat disimpulkan bahwa IRR Bakso Lotus Jembar dapat dikatakan layak. Dimana tingkat suku bunga diskon (discount factor) adalah sebesar 37\%. Sehingga hasilnya IRR $>37 \%$ yaitu $38 \%$ yang melebihi tingkat suku bunga pinjaman.

\subsubsection{Profitability Index (PI)}

Perhitungan ini dilakukan untuk menghitung perbandingan antara nilai penerimaan laba bersih sekarang dan laba dimasa yang akan datang dengan nilai investasi yang dikeluarkan. Perhitungan tersebut menggunakan rumus sebagai berikut :

Kriteria penilaian :

- Jika PI >1, maka usulan proyek dikatakan menguntungkan.

- Jika PI $<1$, maka usulan proyek tidak dikatakan tidak menguntungkan. $=484.246 .500+592617000+$ $726711500+1053126500$ $\frac{(1,0475)(1,0972)(1,1493)(1,2038)}{1.232 .766 .000)}$

$$
\mathrm{PI}=\frac{2.509 .548 .432}{1.232 .766 .000}
$$$$
\mathrm{PI}=2.0
$$

PV kas bersih telah didapatkan pada saat menghitng NPV sebelumnya. Berdasarkan hasil perhitungan diatas nilai PI untuk Bakso Lotus Jembar dapat dikatakan layak. Karena hasil nilai PI tersebut adalah 2.0. $0>1$ usulan dapat dikatakan baik dilanjutkan.

\subsubsection{Teknis dam Operasi}

Berdasarkan hasil wawancara dengan owner, pertimbangan membuka usaha ini adalah karena awalnya keluarga merantau dari solo kemudian menetap di kota bandung dan mendirikan usaha bakso ini sampai sekarang.

Untuk kesesuaian luas produski yang dipertimbangkan adalah bagaimana kapasitas untuk peratan serta lay out dari tata letak pakah mampu menghasilkan kinerja yang lebih efektif dan efisien serta memperkecil tingkat kecelakaan kerja. Berikut tata letak produksi Bakso Lotus Jembar:

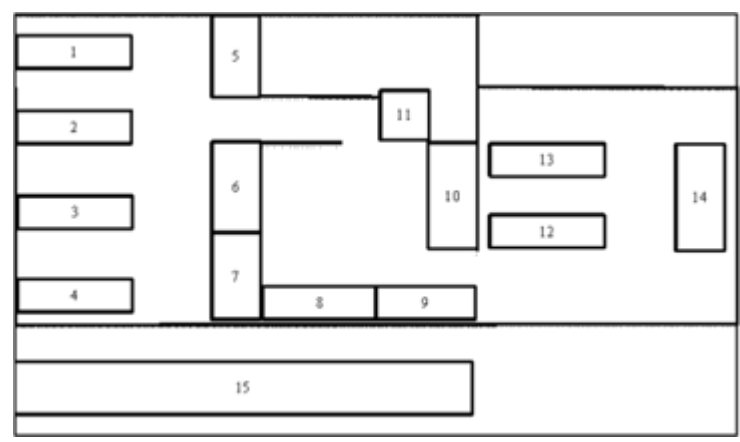

Sumber: data diolah penulis, 2018

Gambar 1. Tata Letak Bakso Lotus Jembar Keterangan:

1) Meja makan

2) Meja makan

3) Meja makan

4) Meja makan

5) Meja makan

6) Kasir dan pemesanan

7) Tempat pengambilan air dan produk

9) Bagian produksi bakso

10) Tempat peralatan dan perlengkapan

11) Toilet untuk konsumen

12) Meja makan

13) Meja makan

14) Meja makan

15) Parkir motor minuman

8) Bagian produksi bakso

Dilihat dari hasil tersebut maka dapat dikatakan Bakso Lotus Jembar dalam aspek teknis dan operasi dapat dikatakan layak untuk diteruskan.

\subsubsection{Aspek Manajemen dan Organisasi}

Dalam aspek manajemen dan organisasi adalah salah satu aspek yang penting dalam suatu perusahaan. Dimana 
semua aktifitas operasional kerja maupun dalam produksi akan lebih terarah dan efektif jika sudah ada sistem manajemen yang baik. Berikut adalah struktur organisasi bakso lotus jembar:

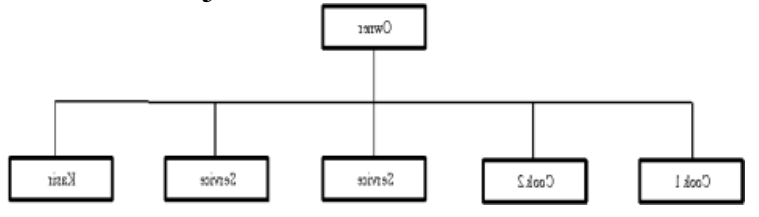

Sumber: Data diolah penulis, 2018

Gambar 2. Struktur Organisasi Bakso Lotus Jembar

Dalam perencanaan untuk tugas dan tanggung jawab karyawan belum ada perencanaan yang khusus maupun pada perencanaan yang memiliki SOP. Hal yang paling diutamakan adalah tentang kejujuran serta etos kerja yang baik.

Untuk pelaksanaan kerja owner menuturkan bahwa sudah ada SOP namun belum dibuat secara tertulis dan dipatenkan. SOP tersebut masih dalam bentuk pengawasan oleh owner. Diantaranya yaitu:

a. Jam buka Baso Lotus Jembar pukul 10.00-21.00.

b. Dari jam 06.00-10.00 produksi bakso dan segala persiapan untuk membuka resto.

c. Persiapan untuk operasional kerja oleh karyawan.

d. Menyiapkan peralatan dan perlengkapan.

e. Membersihkan tempat dan segala persiapan untuk membuka resto.

f. Memperhatikan dan menjaga untuk kesehatan dan keselamatan kerja.

g. Melayani konsumen dengan sopan dan ramah tamah.

h. Kebersihan personal harus diperhatikan dalam melayani konsumen.

Pengawasan yang dilakukan oleh owner berupa pengawasan langsung karena owner pun ikut membantu dalam operasional kerja. kemudian dalam satu minggu sekali diadakan evaluasi untuk mengontrol kinerja karyawan.

Berdasarkan hasil analisis aspek manajemen dan organisasi maka dapat disimpulkan bahwa dari segi aspek manajemen dan organisasi Bakso Lotus Jembar sudah baik dan layak untuk dikembangkan lebih lanjut. Meskipun ada beberapa hal yang perlu ditingkatkan kembali.

\subsubsection{Aspek Sumber Daya Manusia}

Dilihat dari hasil analisis wawancara bersama owner untuk aspek sumber daya manusia maka dari mulai perencanaan pengadaan sdm hingga rencana seleksi sampai orientasi berbanding positif dengan hasil temuan wawancara bersama karyawan Bakso Lotus Jembar. Begitupun dengan indikator sdm yang lainnya seperti kompensasi, pengembangan, pelatihan serta pemaliharaan kesehatan dan keselamatan kerja terhadap karyawan.

Maka dari itu untuk studi kelayakan bisnis Bakso Lotus Jembar dilihat dari aspek manajemen sumber daya manusia sudah dapat dikatakan layak.

\subsubsection{Aspek Ekonomi}

Dalam aspek ekonomi hal yang dilihat adalah bagaimna kontribusi suatu usaha terhadap lingkungan sekitarnya. Dengan diibukanya Bakso Lotus Jembar ini cukup membantu masyarakat untuk membuka kesempata kerja serta dapat menumbuhkan industri lain seperti menumbuhkan supplier lokal dalam pengadaan bahan baku.

Dilihat dari hasil analisis aspek keuangan tersebut studi kelayakan bisnis Bakso Lotus Jembar dari aspek keuangan tersebut sudah dapat dikatakan layak.

\subsubsection{Aspek Sosial dan Budaya}

Berdasarkan hasil wawancara bersama owner bahwa dengan dibukanya usaha ini cukup berpartisipasi menciptakan lapangan kerja baru. Untuk saat ini karyawan Bakso Lotus Jembar sebagian besar bukan merupakan warga asli daerah kota bandung melainkan dari luar daerah kota bandung seperti garut dan sukoharjo. Tentu hal ini dapat membantu untuk meningkatkan mutu hidup karyawan tersebut. 
Dilihat dari hasil analisis tersebut maka studi kelayakan bisnis Bakso Lotus Jembar sudah dapat dikatakan layak meskipun ada beberapa hal yang harus diperbaiki.

\subsubsection{Aspek Politik}

Dilihat dari hasil analisis dengan mewawancarai owner menuturkan bahwa jika ada muncul isu tentang bakso boraks maupun bakso yang terbuat dari bukan daging sapi itu akan mempengaruhi terhadap penjualan. Penjualan bisa menurun. Namun cara mengatasinya kita perlu kepercayaan terhadap konsumen yang loyal serta hal yang utama adalah harus tetap menjaga rasa dan kualitas produk dengan baik.

Berdasarkan hasil analisis aspek politik studi kelayakan bisnis Bakso Lotus Jembar maka dapat dilihat bahwa Bakso Lotus Jembar belum layak karena belum memiliki perizinan untuk mendirikan usaha yang sudah menjadi kebijakan pemerintah dan itu pun adalah salah satu hal yang penting untuk mengatasi jika ada permasalahan hukum yang dapat merugikan bisnis tersebut dikemudian hari.

\section{Kesimpulan}

Berdasarkan hasil penelitian keseluruhan aspek - aspek studi kelayakan bisnis Bakso Lotus Jembar maka terdapat beberapa kesimpulan yaitu secara keseluruhan aspek-aspek tersebut sudah dapat dikatakan layak untuk dilanjutkan namun dengan beberapa rekomendasi.

Untuk aspek internal sudah dapat dikatakan layak namun ada beberapa aspek yang perlu diperbaiki dan ditingkatkan. Yaitu untuk aspek hukum perlu diperlu di penuhi perihal semua kewajiban untuk izin usaha. Aspek pasar dan pemasaran sudah berada dalam kategori baik maka perlu dipertahankan baik itu kulitas produk, harga dan tempat, untuk promosi supaya lebih dimaksimalkan kembali untuk meningkatkan penjualan. Aspek keuangan sudah dalan keadaan baik berdasarkan perhitungan metode penilaian investasi. Aspek teknis dan operasi sudah dapat dikatakan layak dengan beberapa perbaikan yaitu perlu ditinjau ulang tentang peralatan yang dipakai untuk lebih meningkatkan kemenarikan kualitas produk. Aspek manajemen dan organisasi sudah dapat dikatakan layak. Baik untuk perencanaan, pelaksanaan serta pengawasan dengan rekomendasi untuk pelaksanaan kerja sebaiknya dibuat SOP yang secara tertulis untuk memaksimalkan tugas dan tanggung jawab karyawan. Aspek manajemen sdm sudah dapat dikatakan layak dengan rekomendasi bahwa untuk kompensasi karyawan sebaiknya dapat didaftarkan untuk kompensasi yang sudah resmi untuk menjamin kesejahteraan karyawan.

Berdasarkan hasil penelitian untuk aspek eksternal dapat dikatakan layak dengan beberapa rekomendasi yaitu untuk aspek politik karena aspek ini masih berhubungan dengan aspek hukum maka rekomendasi tetap sama yaitu untuk segera memenuhi perizinan usaha untuk mencegah terjadinya plagiarisme dan penagmbilan nama merek dagang oleh pesaing.

\section{Daftar Pustaka}

Johan, Suwinto. 2011. Studi Pengembangan Bisnis. Yogyakarta: Graha Ilmu

Kasmir \& Jakfar. 2012. Studi Kelayakan Bisnis. Cetakan Ke Delapan. Jakarta: Kencana.

KBBI ONLINE Di akses tanggal 20/03/2018(kbbi.web.id/p ariwisata)

Kotler, dan Keller. 2012. Manajemen Pemasaran, Edisi 12. Jakarta: Erlangga.

Margono. 2004. Metodologi Penelitian Pendidikan. Jakarta: Rineka Cipta.

Marsum, W.A. 2005. Restoran dan Segala Permasalahannya. Yogyakarta.: ANDI.

Sugiyono. 2012. Metode Penelitian Bisnis. Bandung :Alfabeta

Umar, Husein. 2003. Studi kelayakan bisnis .Jakarta

:Gramedia Pustaka Utama. 
Undang-Undang Republik Indonesia No. 10

Tahun 2009. Pasal 1 Tentang

Kepariwisataan. 